\title{
EFFECTS OF PHYSOSTIGMINE ON RAT BRAIN ACETYLCHOLINE, ACETYLCHOLINESTERASE AND CONDITIONED POLE JUMPING*†
}

\author{
John A. Rosecranst, Anthony T. Dren $\S$, and Edward F. Domino \\ Department of Pharmacology, Univ. of Michigan, Ann Arbor, Michigan
}

(Accepted 20 July 1967)

\begin{abstract}
Summary - The present study was designed to provide evidence that the behavioral effects of physostigmine are related to inhibition of brain acetylcholinesterase (AChE). Adult male Holtzman rats were trained to pole jump to a buzzer as the conditioned stimulus and to electric shock to the grid floor as the unconditioned stimulus. All drugs were given s.c. as base. Physostigmine $(0.125-0.25 \mathrm{mg} / \mathrm{kg})$ depressed pole jump behavior in methyl atropine $(2.1$ $\mathrm{mg} / \mathrm{kg}$ ) or saline-treated rats. (-) Hyoscyamine $(1 \mathrm{mg} / \mathrm{kg})$ blocked the actions of physostigmine, suggesting a central site of action.

Total brain acetylcholine (ACh) and $\mathrm{AChE}$ were determined in various groups of animals. The increase in brain $\mathrm{ACh}$ and the decrease in $\mathrm{AChE}$ activity were negatively correlated in physostigmine-treated rats. These changes were highly correlated during the onset and peak of physostigmine behavioral effects but not during the recovery period. Although (-) hyoscyamine antagonized the behavioral effects of physostigmine, it did not alter the increase in brain ACh or decrease in brain AChE. It is concluded that most of the behavioral effects of physostigmine are related to central AChE inhibition.
\end{abstract}

\section{INTRODUCTION}

ONE Or the most important tasks of the neuropharmacologist is to correlate the behavioral effects of centrally acting drugs with their biochemical actions. Physostigmine is a drug well suited for such studies because its neurochemical effects are well documented and easily measured. Its relatively rapid onset and short duration of action make it especially desirable. This reversible cholinesterase inhibitor has been used successfully to study central cholinergic mechanisms and their relationship to behavior. PFEIFFER and JENNY (1957) observed that physostigmine was a potent depressant of learned behavior (pole-jump response). They ascribed its site of action to the central nervous system since physostigmine-induced behavioral depression was prevented by atropine pretreatment, whereas methyl atropine offered little protection. GolDBERG et al. $(1963,1965)$ attempted to correlate rat brain cholinesterase activity with inhibition of discrete shock avoidance behavior produced by three different anticholinesterases. The compounds studied included: 3-iso-propylphenyl carbamate (compound 10854), naphthyl N-methyl carbamate (carbaryl) and physostigmine. These investigators obtained a correlation between the behavioral

\footnotetext{
*Supported in part by the Michigan Neuropsychopharmacology Research Program, USPHS, Grant MH11846-01

${ }^{+}$A preliminary report of this investigation appeared in Fedn Proc. Fedn Am. Socs exp. Biol. 25: 261 (1966).

$\Varangle$ Postdoctoral Fellow NIH, MH-10,570-02. Present address: Department of Pharmacology, Medical

College of Virginia, Richmond, Virginia.

\$Present adldress: Department of Pharmacology, Abbott Laboratories, North Chicago, Illinois.
} 
depression produced by increasing doses of these drugs and inhibition of brain cholinesterase. However, at equipotent anticholinesterase inhibiting doses, a greater behavioral depressant effect was observed with physostigmine and carbaryl than compound 10854 . Atropine sulfate significantly blocked the behavioral effects produced by all three agents. Un the basis of these studies, GioldBerg et al. $(1963,1965)$ concluded that physostigmine and carbaryl had a direct cholinergic agonist component which was not as prominent with compound 10854 .

The present investigation was designed to provide further evidence that the behavioral effects of physostigmine are related to its actions as a cholinesterase inhibitor. Both brain acetylcholine $(\mathrm{ACh})$ and acetylcholinesterase $(\triangle \mathrm{ChE})$ activity were measured and compared to the behavioral deficits produced by physostigmine in methyl atropine and ( - ) hyoscyamine-pretreated animals.

\section{METHODS}

Holtzman male albino rats, 90-120 days old, were utilized throughout this investigation. The drugs were dissolved in saline solution and administered s.c. All drug dosage was calculated as base.

Behavioral procedures. Twenty-four animals were trained to acquire the pole jump response of COOK and WEIDLFy (1957) as modified by MeYers et al. (1964). The conditioned stimulus (CS), a buzzer, was presented for $5 \mathrm{sec}$ and overlapped $5 \mathrm{sec}$ with an unconditioned stimulus (US), a $1.0 \mathrm{~mA}, 60 \mathrm{c} / \mathrm{s}$ shock, scrambled through the grid floor. An avoidance response was defined as a pole jump to the CS. An escape response was defined as a pole jump to the US. Inter-trial intervals ranged from 20 to $40 \mathrm{sec}$ with an average of $30 \mathrm{sec}$. Trials were given in blocks of 10 with 1 min between trial blocks. Animals usually attained a $90 \%$ criterion within 100 trials which represented two experimental sessions of 50 trials each. Before any drugs were administered, each animal completed 15 to 18 such experimental sessions. This amounted to 3 sessions per week for 5-6 consecutive weeks. Such animals showed $100 \%$ avoidance behavior and therefore were highly overtrained.

After reaching a stable behavioral baseline each animal was pretreated with saline solution, atropine methyl nitrate $(2.1 \mathrm{mg} / \mathrm{kg})$ or various doses of $(--)$ hyoscyamine $(0.086$ to $1.0 \mathrm{mg} / \mathrm{kg}) 30 \mathrm{~min}$ prior to the administration of physostigmine salicylate $(0.15$ to $0.25 \mathrm{mg} / \mathrm{kg}$ ). Following pretreatment, the animal was placed in the behavioral box and given fifty trials. At the termination of this session the animal was given either isotonic saline or physostigmine and returned to the behavioral chamber for further testing.

AChE Assay. All animals used in thesc cxpcriments were sacrificed by decapitation; each brain was quickly excised, split sagitally and the cerebellum dissected away. The left half of the cerebrum was weighed and homogenized in cold saline $(141 \mu \mathrm{M} \mathrm{NaCl}$, $1: 10$ ), and stored at $4^{\circ} \mathrm{C}$ until assay, usually within $4 \mathrm{hr}$ after sacrifice. One millilitre of homogenate (the equivalent of $100 \mathrm{mg}$ of brain) was diluted $1: 30$ in distilled water. This mixture was placed in a water bath maintained at $37.5^{\circ} \mathrm{C}$ and the $\mathrm{pH}$ adjusted to $7 \cdot 4$. AChE activity was determined by the $\mathrm{pH}$ stat technique (JENSEN-HOLM et al., 1959). A total of $8.3 \mathrm{mg}\left(4.3 \times 10^{-4} \mu \mathrm{M} / \mathrm{g}\right)$ acetyl $\beta$-methylcholine chloride (methacholine) was added to the mixture. The acid liberated from methacholine hydrolysis was neutralized and $\mathrm{pH}$ maintained at 7.4 with $\mathrm{CO}_{2}$ free $\mathrm{NaOH}(0.1$ or $0.05 \mathrm{~N})$ by means of an automatic recording titrator (Radiometer, Inc.). Each analysis was followed for 5-10 min after the 
homogenate blank was determined. Cholinesterase activity was calculated from the quantity of $\mathrm{NaOH}$ added per unit time and cvaluated as $\mathrm{m} \mu \mathrm{M}$ of methacholine hydrolyzed/g of brain/sec. Absolute rates were equivalent to enzymatic hydrolysis of methacholine plus its non-enzymatic hydrolysis which, in these studies, was insignificant.

ACh Assay. Following decapitation, brain tissue was excised, the cerebellum removed, and the right half of the cerebrum frozen in isopentane contained in a beaker surrounded by ethanol and dry ice. The following day the frozen tissue was weighed and pulverized in a stainless steel mortar cooled in dry ice. Brain extracts were prepared by the acidalcohol method (STONE, 1955; CROSSLAND, 1961). The ACh-like activity of the extracts was bioassayed on the isolated frog (Rana pipiens) rectus abdominus muscle preparation. Rectus muscles were mounted in a $4 \mathrm{ml}$ assay chamber containing frog-Ringer's solution $\left(25^{\circ} \mathrm{C}\right)$ and attached to an isotonic lever. Air was bubbled through a sintered glass attachment at the bottom of the muscle bath. A $1.5 \mathrm{~g}$ load was placed on the lever to stretch the muscle and neostigmine salicylate $(6 \mathrm{mg} / 1)$ added to the frog-Ringer's. After a 30-min equilibration period, the load on the lever was reduced to $1.0 \mathrm{~g}$. The isotonic contraction was recorded for 2 min on a smoked paper kymograph. The recorded response represented a $20: 1$ magnification of muscle contraction. The muscle was washed for 5-10 min between consecutive responses. The wash interval was constant for cach muscle preparation. Stock solutions of ACh standards were prepared in frog-Ringer's containing neostigmine. As suggested by FELDBERG (1945), ACh standards were prepared in alkali-inactivated extracts to allow for the presence of sensitizing factors in the brain tissue.

All tabulated data were presented as the mean \pm S.E. Student $t$-tests for group comparison were performed according to SNEDECOR (1956).

\section{RESULTS}

Effect of physostigmine on conditioned pole jump behavior

Increasing doses of physostigmine $(0.15$ to $0.25 \mathrm{mg} / \mathrm{kg}$ s.c.) progressively depressed conditioned avoidance behavior in the rat. Avoidance was affected more than escape. In the above dose range, physostigmine also produced symptoms of cholinergic-induced distress. Therefore methyl atropine and ( - ) hyoscyamine were used as possible antagonists.

The mean data of six overtrained rats given $0.15 \mathrm{mg} / \mathrm{kg}$ of physostigmine $30 \mathrm{~min}$ after saline solution, methyl atropine and ( - ) hyoscyamine pretreatments are given in Table 1.

TABLE 1. EFFECTS OF METIIYL ATROPINE AND ( - ) HYOSCYAMINE PRETREATMENT ON THE ONSET AND DURATION OF PHYSOSTIGMINE $(0.15 \mathrm{mg} / \mathrm{kg})$ INDUCED BEHAVIORAL DEPRESSION

\begin{tabular}{|c|c|c|c|c|}
\hline Pretreatment & $\begin{array}{l}\text { Mean onset } \\
\text { of action } \\
+ \text { S.E. in min }\end{array}$ & $\begin{array}{l}\text { Mean dura- } \\
\text { tion of } \\
\text { action } \pm \\
\text { S.E. in min }\end{array}$ & $\begin{array}{c}\text { Mean \% } \\
\text { avoidance } \\
+ \text { S.E. }\end{array}$ & $\begin{array}{c}\text { Mean \% } \\
\text { of escape } \\
+ \text { S.E. }\end{array}$ \\
\hline Saline & $13 \cdot 1 \pm 1 \cdot 2$ & $37 \cdot 3 \div 2 \cdot 4$ & $12 \cdot 9 \pm 4 \cdot 4$ & $69 \cdot 0 \pm 5 \cdot 6$ \\
\hline $\begin{array}{l}\text { Atropine methyl nitrate } \\
2 \cdot 1 \mathrm{mg} / \mathrm{kg}, \text { s.c. }\end{array}$ & $27 \cdot 2 \pm 1 \cdot 2$ & $14 \cdot 6 \pm 4 \cdot 5$ & $32.9 \pm 13.7$ & $59 \cdot 6 \pm 14 \cdot 9$ \\
\hline $\begin{array}{c}(-) \text { Hyoscyamine } \\
1.0 \mathrm{mg} / \mathrm{kg}, \text { s.c. }\end{array}$ & 0 & 0 & $97 \cdot 3 \pm 0 \cdot 7$ & $2.7 \pm 0.7$ \\
\hline
\end{tabular}


The onset of action was recorded as the avoidance behavior became blocked by $50 \%$ the duration of action was measured from that moment till the avoidance block became less than $50 \%$ The percent depression of avoidance and escape was calculated during the period of at least $50 \%$ depression per block of ten trials. It can be seen that methyl atropine and ( - ) hyoscyamine, in comparison to saline, alter the effects of physostigmine but ( - ) hyoscyamine was much more potent. In saline pretreated animals physostigmine caused $12.9 \%$ avoidance and $69.0 \%$ escape behavior. Methyl atropine clearly had a partial antagonistic action and increased avoidance responses to $32.9 \%$. On the other hand $(-)$ hyoscyamine almost completely antagonized the behavioral effects of physostigmine.

In methyl atropine-pretreated rats, increasing doses of physostigmine produced closerelated depression of avoidance behavior as illustrated in Fig. 1 . A dose of $0.25 \mathrm{mg} / \mathrm{kg}$

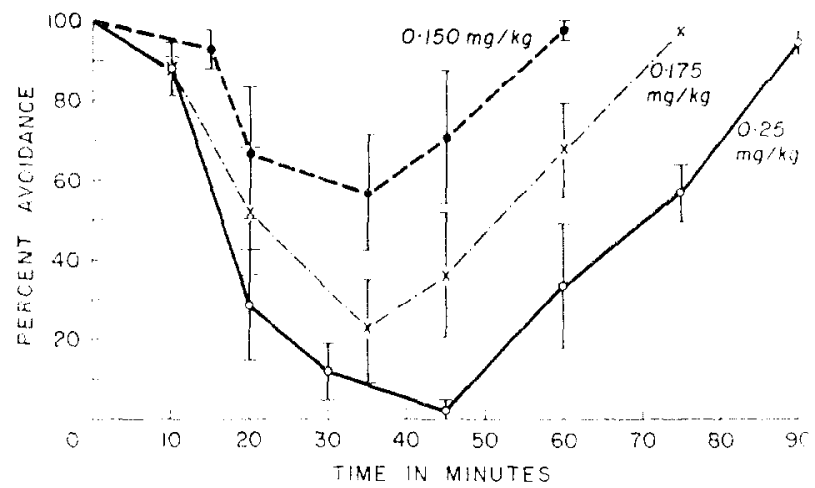

FIG. 1. Effects of physostigmine on conditioned pole jumping in rats.

The mean avoidance behavior $t$ S.E. for each group of six animals following increasing dose of physostigmine is given at various time intervals after injection. The percent avoidance is given per block of ten trials at the times indicated. Methyl atropine $(2.1 \mathrm{mg} / \mathrm{kg}$, s.c.) was given 30 min prior to physostigmine.

of physostigmine produced maximum inhibition of avoidance behavior. Escape behavior, on the other hand, was relatively unimpaired and therefore not plotted. At maximal behavioral depression, animals escaped $88.0+9.4 \%$ of the time, whereas they avoided at a rate of only $2.4 \pm 2.0 \%$. Escape behavior was also markedly depressed in doses, greater than $0.25 \mathrm{mg} / \mathrm{kg}$. Therefore, larger doses were not studied.

In contrast to results obtained with methyl atropine-pretreated animals, an equimolar dose of $(-)$ hyoscyamine completely antagonized the behavioral depression produced by $0.25 \mathrm{mg} / \mathrm{kg}$ of physostigmine. Because of the graded effect obtained with several doses of $(-)$ hyoscyamine, this antagonism appeared to be competitive. This effect is clearly evident in Fig. 2.

\section{Time course of physostigmine-induced alterations in brain ACh and AChE}

Since $0.25 \mathrm{mg} / \mathrm{kg}$ physostigmine was most effective in depressing avoidance behavior in methyl atropine-pretreated animals, this dose was used to determine the temporal relationship between ACh accumulation, AChE inhibition and avoidance behavior (Fig. 3). Sacrifice times were selected to correspond to the onset, maximum and termination of hehavioral depression. Both $\mathrm{ACh}$ and $\mathrm{AChE}$ levels were significantly different $(P-0.05)$ 


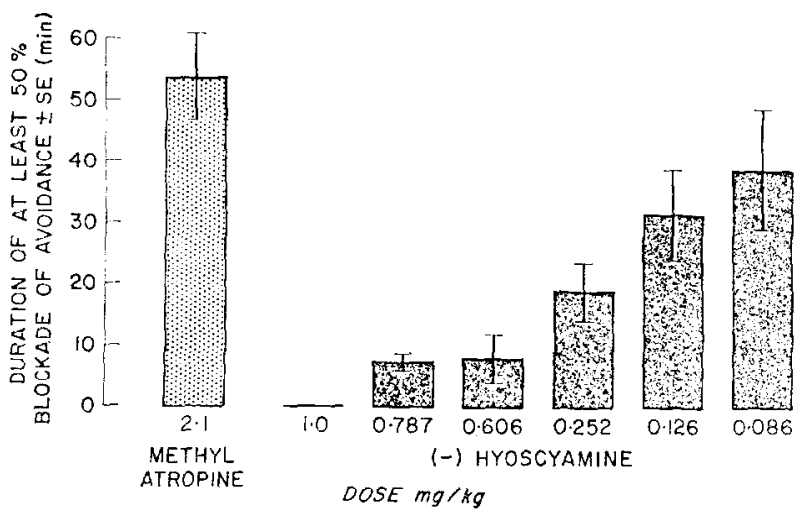

FIG. 2. Differential effects of methyl atropine and $(-)$ hyoscyamine on the duration of physostigmine induced depression of avoidance behavior.

The duration of at least 50 per cent blockade of avoidance behavior was determined between the onset and recovery of 50 per cent avoidance per group of ten trials following physostigmine $(0.25 \mathrm{mg} / \mathrm{kg})$. Fach bar represents the mean of six animals. The muscarinic blocking drugs were administered $30 \mathrm{~min}$ prior to physostigmine.

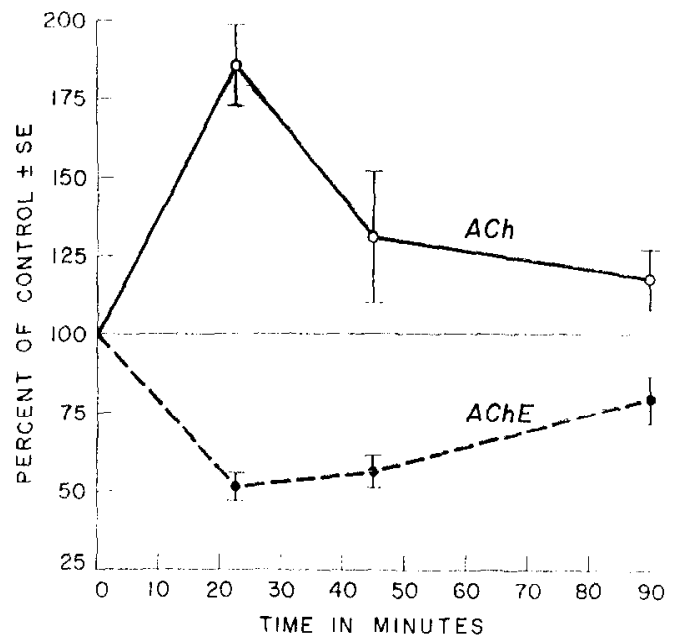

FIG. 3. Time course of rat brain ACh accumulation and AChE inhibition following physostigmine.

Each point represents the mean \pm S.F. of four separate groups of methyl atropine $(2 \cdot 1 \mathrm{mg} / \mathrm{kg})$ pretreated aninals. Control ACh Levels $=13.7+1.7 \mathrm{~m} \mu \mathrm{M} / \mathrm{g}$ as acetylcholine chloride and control AChE levels $=86.0 \pm 1.9 \mathrm{~m} \mu \mathrm{M} / \mathrm{g} / \mathrm{sec}$.

from controls at the onset of behavioral depression. ACh accumulation and concurrent $\mathrm{AChE}$ inhibition occurred within the time of the avoidance depression. The increase in $\mathrm{ACh}$ was significant primarily at the onset of behavioral depression, whereas AChE levels were significantly lower than control levels both at the time of the onset of depression and at that of maximal effect of the drug $(P<0.01)$. It is also interesting to note that the induced chemical changes persisted beyond 90 min after injection. 
Although (-) hyoscyamine was an effective antagonist of physostigmine-induced behavioral depression it did not significantly modify the alteration of brain ACh and AChE (Fig. 4). With the doses used, neither methyl atropine nor (-) hyoscyamine alone had a significant effect on either brain $\mathrm{ACh}$ or depressed conditioned avoidance behavior in these highly overtrained animals.
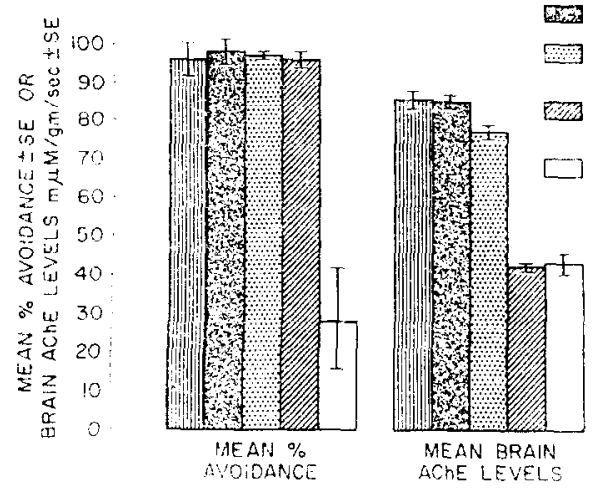

METHYL ATROPINE $(2, \mathrm{mg} / \mathrm{kg})$

7 (-) HYOSCYAMINE (1.Omg/kg)

(-) HYOSCYAMINE $(10 \mathrm{mg} / \mathrm{kg})$ + PHYSOSTIGMINE $(0.25 \mathrm{mg} / \mathrm{kg})$ METHYL ATROPINE $(2 \cdot 1 \mathrm{mg} / \mathrm{kg})$ + PHYSOSTIGMINE $(0.25 \mathrm{mg} / \mathrm{kg})$

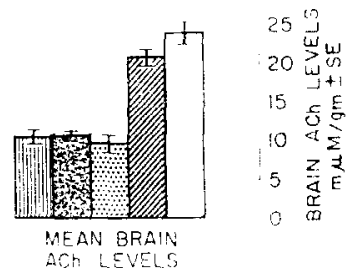

Fig. 4. Interaction between methyl atropine, ( ) hyoscyamine and physostigmine.

Each group of animals were given ( .) hyoseyamine, methyl atropine or saline. After 30 min two of the treated groups were given physostigmine $(0.25 \mathrm{mg} / \mathrm{kg})$ as shown. All estimations were obtained $20 \mathrm{~min}$ thereafter. Each bar represents the mean : S.E. of at least six animals.

\section{Dissociation of AChE inhibition and recovery of behavior following phy'sostigmine}

It was noted that physostigmine produced a dose-effect relationship in the depression of avoidance behavior as well as inhibition of brain AChE. However, there was a clear dissociation between the recovery of behavior and $\mathrm{AChE}$ inhibition. Behavioral recovery occurred within 60-90 min after physostigmine. At this time, $\mathrm{ACh}$ and $\mathrm{AChE}$ levels were still altered 21 to $23 \%$ as compared to control. This can be observed in Figs. 1 and 3 for $0.25 \mathrm{mg} / \mathrm{kg}$ of physostigmine. A similar dissociation during the recovery period was noted for 0.15 and $0.175 \mathrm{mg} / \mathrm{kg}$ of physostigmine as well in other series of animals.

\section{DISCUSSION}

Physostigmine has mixed central and peripheral actions which may influence behavior. In addition to an intended central effect, physostigmine may induce skeletal muscle fasciculations, salivation, lacrimation, urination and diarrhea (SLUD syndrome) although this syndrome was not as evident as we had expected. Nevertheless, the quaternary muscarinic (m)-cholinergic blocking agent methyl atropine was used to reduce these possible peripheral effects. In the doses used, methyl atropine does not have any behavioral effects and no change in brain ACh and AChE was observed. Not all of the peripheral actions of physostigmine are blocked by methyl atropine. For example the peripheral nicotinic (n)-cholinergic actions at the skeletal neuromuscular junction are not antagonized. Our data clearly show that methyl atropine partially antagonizes the depressant effects of physostigmine on avoidance behavior indicating that peripheral cholinergic stimulation impairs 
the might-be expected behavioral performance. Thus the use of methyl atropine pretreatment is indicated in correlating alterations in brain levels of $\mathrm{ACh}$ and of $\mathrm{AChE}$ with behavioral effects of cholinesterase inhibitors.

The degree of $\mathrm{AChE}$ inhibition in vivo and its relationship to behavior requires cautious interpretation. Even though animals avoided at pre-injection rates $60-90 \mathrm{~min}$ after physostigmine, brain AChE was only $79 \%$ of control. Since these animals were apparently performing normally, one might conclude that $\mathrm{AChE}$ must be inhibited by more than $21 \%$ before learned behavior is altered. GOLDBERG et al. (1963) found that cholinesterase activity must be inhibited 25 to $50 \%$ to affect avoidance behavior in a similar task. In addition, they observed that avoidance behavior returned before recovery from AChE inhibition.

A large amount of $\mathrm{AChE}$ in the brain occurs intraneuronally and may not participate in synaptic function. In correlative in vivo-in vitro studies such as the present, it should be realized that homogenization of brain tissue brings molecules of inhibitor and enzyme into contact which may not have been responsible for the behavioral events occurring immediately prior to brain removal. Thus, the percent of AChE inhibition measured in vitro should be considered as indicative of the total concentration of inhibitor and enzyme in the brain, rather than the actual degree of $\Lambda \mathrm{ChE}$ inhibition in vivo. When AChE inhibition is measured manometrically or titrimetrically, in vitro, following the administration of a "reversible" inhibitor such as physostigmine, homogenization and dilution involved in the procedures cause a reversal of the inhibition. Thus the inhibition recorded probably is less than that which actually occurred. Furthermore, at present there is no method of determining the actual in vivo concentrations of ACh at critical physiological receptor sites. Hopefully, the degree of $\mathrm{AChE}$ inhibition and $\mathrm{ACh}$ at the receptor site is proportional to the measurements made. Assuming that the data obtained reflect the true state of affairs, one can conclude that the behavioral actions of physostigmine under the conditions of these experiments are indirect, i.e. the result of $\mathrm{ACh}$ accumulation at m-cholinergic reception sites. Furthermore, $(-)$ hyoscyamine antagonizes the behavioral depression by competing with $\mathrm{ACh}$ at these same central sites. It should be realized we are referring to an $\mathrm{ACh}$-like substance since a nonselective bioassay technique was used. However, numerous investigators have shown that this $\mathrm{ACh}$-like substance has pharmacologic actions and chemical properties similar to ACh (CROSSLAND and REDFERN, 1963; Mclennen et al., 1963; Pepeu et al., 1963; Szerb, 1963: Ryall et al., 1964; Whittaker and Dowe, 1964; and Stavinoha and Ryan, 1965).

Although the present study suggests that physostigmine acts by preventing $\mathrm{ACh}$ destruction, there is the possibility that the drug may act independent of $\mathrm{AChE}$ inhibition. It is known, for example, that large doses of physostigmine have a direct blocking action on autonomic ganglia (Paton and Perry, 1953). Recently Bradley (1967) demonstrated an action of physostigmine different from that of $\mathrm{ACh}$ on micro-electrophoretic injection on brainstem neurons. Furthermore, physostigmine may release other potential neurotransmitters such as serotonin (APRISON et al., 1962) and catecholamines (CABRERA et al., 1966). The fact that $(-)$ hyoscyamine so effectively antagonizes the behavioral actions of physostigmine seems to rule out a direct role of biogenic amines in its actions.

\section{REFERENCES}

APRISON, M. H. (1962). On a proposed theory for the mechanism of action of serotonin in brain. Recent Advances in Biol. Psychiat. 4: 133-146. 
13kADLEY, P. B. (1967) Effects of acetylcholine, nicotine, and muscarine on brain stem neurons. $11 m ., N, r$ Acad. Sci. 142: 15-20.

CABrl:RA, R., Torrance, R. W. and Viveros, H. (1966). The action of acetylcholine and other drugs upoul the terminal parts of the postganglionic sympathetic fibre. Br.J. Pharmac. 27:51-63.

Cook, L. and WEIDLEY, E. (1957). Behavioral effects of some psychopharmacological agents. $1 \mathrm{n} n, \mathrm{~N} . \mathrm{Y}$ Acacl. Sci. 66: 740-572.

Crossland, J. (1961). Biologie estimation of acetylcholine. Meth. med. Re's. 9: 125-129.

Crossland, J. and Rforern, P. H. (1963). Chromatographic behavior of acetylcholine in bram extracts. Life Sci, 10: $711-716$.

l'LLDBERG, W. (1945). Present views on the mode of action of acetykholine on the central nervous system. Physiol. Re'. 25: 596-642.

Goldberc, M. E., Johnson, H. E., Knaak, J. B. and Simyth, H. F., Jr. (1963). Psychopharmacological cffects of reversible cholinesterase inhibition induced by N-Methyl 3-isopropylphenyl carbamate (compound 10854). J. Pharmac. exp. Ther. 141: 244-252.

Goloberc, M. E., JoHNSON, H. E. and KNAAK, J. B. (1965). Inhibition of discrete avoidance behavior by three anticholinesterase agents. Psychopharmacologia 7: 72-76.

Jlensen-Holm, J., LAusen, H. H., Milthers, K. and Møller, K. O. (1959). Determination of the cholincsterase activity in blood and organs by automatic titration. With some observations on serious crrors of the method and remarks of the photometric determination. Acta pharmac, tox. 15: 384-394.

Mollinnan, H., Curry, L. and Walker, R. (1963), The chromatographic behavior of the acetyleloline: activity of brain extracts. Bischem. J. 89: 163-166.

Meyers, B., Roberts, K. H., Riciputi, R. and Domino, E. F. (1964). Some effects of muscarinic cholinergic blocking agents on behavior and the electrocortigram. Psychopharmacologia 5: 289-300.

PAION, W. D. M. and Ptekr, W. L. M. (1953). The relationship between depolarization and block in the: cal's superior cervical ganglion. J. Physiol., Lond. 119: 43-57.

P'LPEu, G., Schmidt, K. F. and Giarman N. J. (1963). Identity with authentic acetylcholine of acely) choline-like activity in extracts of rat brain. Biochem. Pharmac. 12: 385-388.

Plitithe, C. C. and JiNvy, E. H. (1957). Inhibition of conditioned response and the counteraction of schizophrenia by muscarinie stimulation of the brain. Anlm. N. Y. Acud. Sci. 66: 753-764.

Rinit, R. W., Srone, N. E., Curtis, D. L. and Watkins, J. C. (1964). Action of acetylcholine extractes from brain and spinal Renshaw cells. Nesture, Lond. 201: 1034-1035.

Sinidicok, G. W. (1956). Statistical Methods. The Iowa State College Press, Ames, Iowa, 5th Edition.

SINVINoHA, W. B, and RYAN, L. C. (1965). Estimation of the acetylcholine content of rat brain by gas chromatography. J. Pharmac. exp. Ther, 150:231-235.

SHoNe, W. E. (1955). Acetylcholine in the brain. 1. "Free, Bound" and total acetykholine. Archs Birchem Biophys. 59: 181-192.

SzLRB, J. C. (1963). Nature of acetylcholine-like activity released from brain in virr. Nature, Lond, 197: $1016-1017$.

WhImAKtre, V. P. and Duwe, G. H. C. (1964). The identification ol the acetylcholine-like substance in synaptosomes derived from guinea-pig brain as acetylcholine itself. Int. J. Ncuropharmacol. 3: 593-597. 